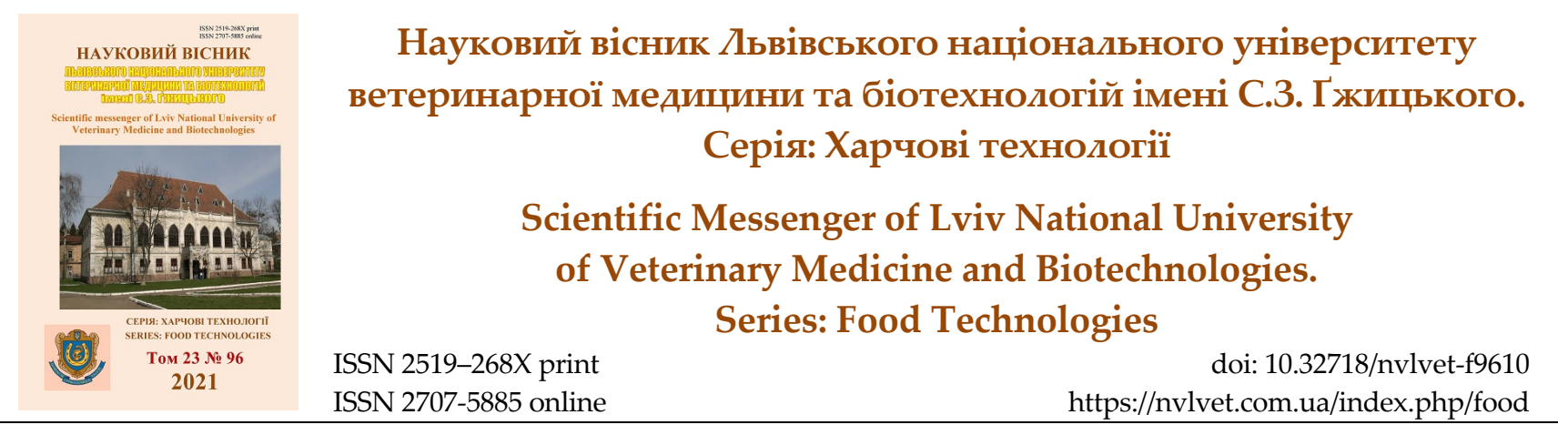

UDC 631.95:640.2

\title{
Environmental management in the hotel and restaurant complex
}

\author{
T. Lebedenko, G. Krusir, H. Shunko, V. Sokolova, T. Sokolova, A. Makas \\ Odessa National Academy of Food Technology, Odesa, Ukraine
}

Article info

Received 10.05.2021

Received in revised form 14.06.2021

Accepted 15.06.2021

Odessa National Academy of Food Technologies, Kanatna Str., 112, Odesa, 65039, Ukraine. E-mail:krussir.65@gmail.com
Tel.: +38-097-909-91-77

Lebedenko, T., Krusir, G., Shunko, H., Sokolova, V., Sokolova, T., \& Makas, A. (2021). Environmental management in the hotel and restaurant complex. Scientific Messenger of Lviv National University of Veterinary Medicine and Biotechnologies. Series: Food Technologies, 23(96), 54-60. doi: $10.32718 /$ nvlvet-f9610

In the current context, significant changes are taking place in the structure of Ukrainian industry. Powerful productions of some spheres of activity lose their urgency and, on the contrary, acquire the development of power of other branches, namely, craft productions, to the composition of which the company belongs. The result of the activity of the businesses complex is the formation of significant volumes of food waste (about 160 thousand ton), discharges of concentrated wastewater, wastewater discharges. The wastes of the restaurant industry have a wide nomenclature and a specific composition, under the conditions of their placement in the components of the environment form the ecological aspects of the negative effects. Food wastes of facility in this branch contain a significant amount of nutrients, organic substances and require complex processes of their processing. Meanwhile, according to their composition, production wastes can be involved in the transfer process with the removal of secondary raw materials and energy sources. Thus, there is a need to improve existing and new technologies for the transfer of hazardous waste in order to reduce the load on the environment. The results of the analysis of world and domestic developments in the field of technologies for the utilization of food waste allowed to determine the main methodological approaches to the transition. In the case of the utilization of food waste, biotechnological methods represent a significant interest. Thus, the work is devoted to the connection of the actual scientificpractical task, which consists in the scientific substantiation and improvement of the technology of the transfer of the population's needs.

Key words: environmental aspects, restaurant government, food items, utilization, environmental protection.

\section{Екологічний менеджмент в готельно-ресторанному комплексі}

\author{
Т. Лебеденко, Г. Крусір, Г. Шунько, В. Соколова, Т. Соколова, А. Макас \\ Одеська національна академія харчових технологій, м. Одеса, Украӥна
}


Ключові слова: екологічні аспекти, ресторанні господарства, харчові відходи, утилізація, природоохоронні заходи.

\section{Вступ}

Оскільки харчові відходи належать до органічних відходів, що легко розкладаються, їхня утилізація 3 використанням мікробіологічних процесів та перетворення відходів на вторинний матеріальний ресурс дозволить суттєво зменшити екологічне навантаження підприємств ресторанного господарства на компоненти довкілля. Проте на сьогодні цей метод переробки харчових відходів в Україні не користується широкою популярністю через тривалий процес реалізації компостування та недоліки технологічної організації (Hassen et al., 2001; Jouraiphy, 2005; Gworek et al., 2016; Sagdeeva et al., 2018).

Результатом діяльності підприємств ресторанного господарства $є$ щорічне утворення значних обсягів відходів, які розміщуються на звалищах та полігонах твердих побутових відходів. Однак більшість харчових відходів можуть бути використані як цінна вторсировина. Біотехнологічна переробка харчових відходів на корисні продукти $є$ найбільш доцільною та ефективною з екологічної та економічної точки зору. Біотехнологічні процеси переробки базуються на природних процесах, які практично не мають побічних ефектів, є продуктивними і безпечними для біоти та компонентів навколишнього середовища. Перспективним $є$ спосіб компостування харчових відходів 3 використанням мікробіологічних домішок для прискорення процесів компостування 3 одержанням органічних добрив та зменшенням впливів на навколишне середовище, що обгрунтовує необхідність та доцільність удосконалення існуючих та розробки нових технологічних рішень поводження з харчовими відходами ресторанної галузі (Zyhun, 2011; De Menna et al., 2018).

\section{Матеріал і методи досліджень}

Експертний метод оцінки екологічних аспектів знаходить широке використання при оцінці істотних аспектів системи екологічного менеджменту суб' єктів господарювання, що відповідає одній із ключових вимог до СЕМ відповідно ДСТУ ISO 14001:2015.

Визначення величини пріоритетності екологічних аспектів проводиться експертним шляхом на основі зіставлення та оцінки характеристик масштабності, регульованості, терміновості окремих екологічних аспектів, при обліку рівня екологічного ризику внаслідок можливої аварії з багаторазовим збільшенням рівня впливу на навколишнє середовище.

Оцінка пріоритетності екологічного аспекту проводиться за такою формулою:

Пріоритетність $=$ масштабність + регульованість + терміновість + ризик

Визначення величини масштабності (масштабність)

Для кожного певного аспекту необхідно провести оцінку масштабності за такими характеристиками:

- Чи потрапляє аспект під напрями, визначені екологічною політикою;
- Чи пов’язаний екологічний аспект або дія 3 використанням невідновлюваних природних ресурсів або сировини і матеріалів;

- Чи є можливість застосування до даного екологічного аспекту кращої з доступних технологій або існує необхідність заміни старого обладнання на нове.

При трьох позитивних відповідях аспект оцінюється як великої масштабності, при двох позитивних відповідях - середньої масштабності, при одній малої масштабності. Рівень масштабності може бути охарактеризований чотирма значеннями в балах від "0" до " 3 ":

- Великої масштабності (ВМ) - присвоюється значення “3”;

- Середньої масштабності (CM) - присвоюється значення "2";

- Малої масштабності (ММ) - присвоюється значення "1";

- Відсутність параметра - присвоюється значення “0”.

Визначення величини регульованості впливу на навколишнє середовище (регульованість).

Регулювання характеризується наявністю конвенцій, угод (міжнародних), законодавчих, нормативних правових актів, що регулюють конкретний вид впливу. Оцінюється регульованість за формулою “так” чи "Hi":

- Відповіді “ні” на перераховані вище умови присвоюється значення "0";

- Відповіді “так” - “2”.

Визначення ступеня терміновості зниження рівня впливу (терміновість).

На характеристику терміновості впливають такі чинники:

- Перевищення встановлених норм;

- Думка місцевого населення або персоналу підприсмства;

- Думка громадських організацій;

Оцінюється терміновість по формулі: “так” чи "ні".

При трьох позитивних відповідях або у разі перевищення норм аспект оцінюється як великої терміновості, при двох позитивних відповідях - середньої терміновості, при одному - малої терміновості.

Ступінь терміновості може бути охарактеризована чотирма значеннями в балах від “ 0 ” до “3”:

- Великої терміновості (ВС) - присвоюється значення " 3 ”;

- Середньої терміновості (СС) - присвоюється значення " 2 ";

- Малої терміновості (МС) - присвоюється значення "1"; “0”.

- Відсутність параметра - присвоюється значення

Визначення ризику події (ризик).

Для аспектів при нормальних і анормальних умовах значення ризику дорівнює “0”.

Для кожного ризику оцінюється ймовірність події.

Рівень ризику може бути охарактеризований чотирма значеннями в балах від “ 0 ” до “3”": 
- Великий ризик - (події відбувалися в минулій діяльності структурного підрозділу) - присвоюється значення "3";

- Значний ризик - (події відбувалися в минулій діяльності інших структурних підрозділів підприємства чи галузі) - присвоюється значення “2”;

- Малий ризик - (не було випадків виникнення, але теоретично вони є можливими) - присвоюється значення " 1 ";

- Відсутність параметра - присвоюється значення “0”.

Величина пріоритетності кожного окремого екологічного аспекту буде являти собою суму від 0 до 11 , набрану в результаті відповідей на питання.

Визначення пріоритетності екологічного аспекту.

Визначення пріоритетності екологічних аспектів здійснюється на основі зіставлення виявлених числових характеристик. Для кожного екологічного аспекту оцінюється такий ступінь пріоритетності в балах:

- Мала пріоритетність (МП) - присвоюється значення "0-2";

- Середня пріоритетність (СП) - присвоюється значення "3-5";

Таблиця 1

Характеристика екологічних аспектів системи екологічного менеджменту ресторанного комплексу

\begin{tabular}{|c|c|c|c|}
\hline $\begin{array}{l}\text { Вид діяльності, назва } \\
\text { підрозділу }\end{array}$ & $\begin{array}{c}\text { Технологічний процес, обладнення } \\
\text { - джерела утворення аспекту }\end{array}$ & Екологічний аспект & $\begin{array}{c}\text { Вплив на навколишнє } \\
\text { середовище }\end{array}$ \\
\hline \multirow{2}{*}{$\begin{array}{l}\text { Приготування страв (ово- } \\
\text { чевий, м’ясний, холодний } \\
\text { цехи) }\end{array}$} & Очищення, нарізка сировини & $\begin{array}{l}\text { Сировинні відходи, пакувальні } \\
\text { матеріали, тара }\end{array}$ & Забруднення грунтів \\
\hline & Миття сировини, посуду & $\begin{array}{l}\text { Бруд, залишки грунту, синтети- } \\
\text { чні мийні засоби }\end{array}$ & Скиди стічних вод \\
\hline $\begin{array}{l}\text { Обслуговування ресторану, } \\
\text { бару, банкетного залу }\end{array}$ & $\begin{array}{l}\text { Прибирання бару, конференц- } \\
\text { залу, столиків у ресторані }\end{array}$ & $\begin{array}{l}\text { Папір, битий посуд, пляшки, } \\
\text { зіпсовані меблі }\end{array}$ & Забруднення грунтів \\
\hline $\begin{array}{l}\text { Пральня, миття посуду у } \\
\text { цехах, душові кабінки }\end{array}$ & $\begin{array}{l}\text { Прання робочого одягу та тексти- } \\
\text { лю, миття посуду, використання } \\
\text { душу персоналом }\end{array}$ & $\begin{array}{l}\text { Вуглеводні, синтетичні мийні } \\
\text { засоби }\end{array}$ & $\begin{array}{l}\text { Скиди стічних вод, } \\
\text { викиди в атмосферу }\end{array}$ \\
\hline \multirow[t]{2}{*}{$\begin{array}{l}\text { Автомобільна стоянка, } \\
\text { гараж }\end{array}$} & Робота автомобілів & $\begin{array}{l}\text { Викиди } \mathrm{CO}_{2}, \mathrm{~N}_{\mathrm{x}} \mathrm{O}_{\mathrm{y}} \text {, пари бензину } \\
\text { Пролив та відходи паливно- } \\
\text { мастильних матеріалів, старі } \\
\text { шини та акумулятори, відпра- } \\
\text { цьовані запчастини }\end{array}$ & Викиди в атмосферу \\
\hline & & $\begin{array}{r}\text { Змиті паливно-мастильні мате- } \\
\text { ріали }\end{array}$ & Скиди стічних вод \\
\hline Котельня & Робота котельні & Викиди $\mathrm{CO}_{2}$ & Викиди в атмосферу \\
\hline Холодний, гарячі цехи & \multicolumn{2}{|c|}{ Ризик вибуху обладнення, що працює під тиском } & Викиди та скиди \\
\hline $\begin{array}{l}\text { Овочевий, м'ясний, холод- } \\
\text { ний та гарячий цехи }\end{array}$ & Холодильне обладнення & Ризик псування сировини & Забруднення грунтів \\
\hline
\end{tabular}

Аналіз екологічних аспектів підприємства свідчить про те, що найбільш істотні впливи на компоненти довкілля чинять стічні води, витрати паливноенергетичних ресурсів та харчові відходи, а саме: лушпиння овочів та фруктів і залишки їжі.

3 метою ранжування екологічних аспектів ресторанного закладу доцільно провести їх бальну оцінку за обгрунтованими критеріями, які наведені у таблиці 2.

Аналізуючи екологічні аспекти та їхній вплив на довкілля, виявили, що потужний негативний вплив комплексу спрямований саме на грунт та водне сере-
- Велика пріоритетність (ВП) - присвоюється значення "6-11";

Екологічні аспекти 3 великою пріоритетністю $є$ суттєвими екологічними аспектами. Екологічні аспекти 3 великою і середньою пріоритетністю вносяться в “Реєстр істотних екологічних аспектів" для постановки та реалізації екологічних цілей і завдань. Екологічні аспекти 3 малою пріоритетністю не $\epsilon$ істотними (Boiko et al., 2012).

\section{Результати досліджень}

В ресторанному комплексі екологічні аспекти підрозділів діляться на три основні види: вхідні, вихідні та ризикові. Даний аналіз дозволяє проаналізувати кількісні показники екологічних аспектів, що мають місце в процесі діяльності підприємства, а також побудувати систему ресурс ефективних рішень задля зниження навантаження на довкілля. У таблиці 1 чітко окреслено основні екологічні аспекти, які формуються в процесі функціонування досліджуваного ресторанного комплексу (Krusir \& Sokolova, 2019).

\section{ного менеджменту ресторанного комплексу}




\section{Таблищя 2}

Бальна оцінка екологічних аспектів системи екологічного менеджменту ресторанного комплексу

\begin{tabular}{|c|c|c|c|c|c|c|c|c|}
\hline $\begin{array}{l}\text { Екологіч- } \\
\text { ний аспект }\end{array}$ & $\begin{array}{c}\text { Основні джерела утворення, що складають } \\
\text { понад } 80 \text { \% величини аспекту (назва цеху; назва } \\
\text { технологічного процесу) }\end{array}$ & $\begin{array}{c}\text { Фактичний і потен- } \\
\text { ційно можливий } \\
\text { вплив на навколишнє } \\
\text { середовище }\end{array}$ & 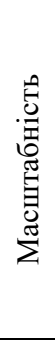 & 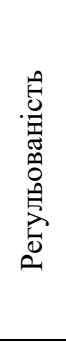 & 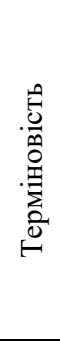 & 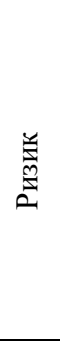 & 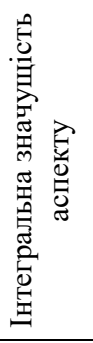 & 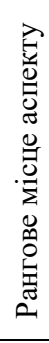 \\
\hline $\begin{array}{l}\text { Сировинні } \\
\text { відходи }\end{array}$ & $\begin{array}{l}\text { М'ясо-рибний і овочеві цехи: приготування } \\
\text { напівфабрикатів } \\
\text { Ризик псування сировини } \\
\text { Ресторан: прибирання столів }\end{array}$ & Забруднення грунтів & 3 & 2 & 3 & 2 & 10 & 1 \\
\hline Папір & $\begin{array}{l}\text { М'ясо-рибний і овочеві цехи: приготування } \\
\text { напівфабрикатів }\end{array}$ & Забруднення грунтів & 1 & 2 & 2 & 0 & 5 & 4 \\
\hline $\begin{array}{l}\text { Битий } \\
\text { посуд }\end{array}$ & $\begin{array}{l}\text { Ресторан: прибирання столів і залу } \\
\text { М'ясо-рибний і овочеві цехи: приготування } \\
\text { напівфабрикатів }\end{array}$ & Забруднення грунтів & 2 & 2 & 1 & 0 & 5 & 4 \\
\hline $\begin{array}{l}\text { Зіпсовані } \\
\text { меблі }\end{array}$ & Зал ресторану, бару & Забруднення грунтів & 1 & 2 & 1 & 0 & 4 & 5 \\
\hline Пакування & $\begin{array}{l}\text { М'ясо-рибний і овочеві цехи: приготування } \\
\text { напівфабрикатів. }\end{array}$ & Забруднення грунтів & 3 & 2 & 2 & 1 & 8 & 2 \\
\hline $\begin{array}{l}\text { Викиди } \\
\mathrm{CO}_{2}\end{array}$ & $\begin{array}{l}\text { Котельня: під час роботи котла } \\
\text { Автомобільна стоянка: під час роботи автомобі- } \\
\text { льних двигунів }\end{array}$ & $\begin{array}{l}\text { Забруднення } \\
\text { атмосфери }\end{array}$ & 3 & 2 & 2 & 1 & 8 & 2 \\
\hline $\begin{array}{l}\text { Викиди } \\
\mathrm{N}_{\mathrm{x}} \mathrm{O}_{\mathrm{y}}\end{array}$ & $\begin{array}{l}\text { Автомобільна стоянка: під час роботи автомобі- } \\
\text { льних двигунів }\end{array}$ & $\begin{array}{l}\text { Забруднення } \\
\text { атмосфери }\end{array}$ & 2 & 2 & 2 & 1 & 7 & 3 \\
\hline $\begin{array}{l}\text { Викиди } \\
\text { парів } \\
\text { бензину }\end{array}$ & $\begin{array}{l}\text { Автомобільна стоянка: під час роботи автомобі- } \\
\text { льних двигунів }\end{array}$ & $\begin{array}{l}\text { Забруднення } \\
\text { атмосфери }\end{array}$ & 2 & 2 & 2 & 1 & 7 & 3 \\
\hline $\begin{array}{l}\text { Паливно- } \\
\text { мастильні } \\
\text { матеріали }\end{array}$ & $\begin{array}{l}\text { Автомобільна стоянка: під час роботи автомобі- } \\
\text { льних двигунів, ризик виникнення течі }\end{array}$ & $\begin{array}{l}\text { Забруднення } \\
\text { атмосфери, грунту }\end{array}$ & 1 & 1 & 1 & 1 & 4 & 5 \\
\hline Вуглеводні & Пральня: очищення одягу та текстилю & $\begin{array}{l}\text { Забруднення стічних } \\
\text { вод }\end{array}$ & 3 & 2 & 2 & 1 & 8 & 2 \\
\hline $\begin{array}{l}\text { Синтетичні } \\
\text { мийні } \\
\text { засоби }\end{array}$ & $\begin{array}{l}\text { Пральня: очищення одягу та текстилю } \\
\text { М'ясо-рибний, овочевий, холодний та гарячий } \\
\text { цехи: під час миття сировини та обладнення }\end{array}$ & $\begin{array}{l}\text { Забруднення стічних } \\
\text { вод }\end{array}$ & 3 & 2 & 2 & 1 & 8 & 2 \\
\hline
\end{tabular}

Оцінюючи вплив сировини, споживання паливноенергетичних ресурсів, стадій технологічного виробництва продукції, підрозділів підприємства, життєвого циклу продукції, вхідних, вихідних та ризикових екологічних аспектів функціонування ресторанного підприємства на навколишнє природнє середовище, доходимо висновку, що дане підприємство в процесі функціонування чинить суттєвий негативний вплив на компоненти довкілля і потребує розробки та впровадження природоохоронних, організаційних, технічних та технологічних рішень. Програма природоохоронних заходів наведена в таблиці 3.

\section{Таблиця 3}

Програма природоохоронних заходів ресторанного господарства

\begin{tabular}{|c|c|c|c|c|}
\hline $\begin{array}{c}\text { Підрозділи, } \\
\text { процеси }\end{array}$ & $\begin{array}{c}\text { Екологічні } \\
\text { аспекти } \\
\end{array}$ & $\begin{array}{c}\text { Природоохоронні } \\
\text { аспекти } \\
\end{array}$ & $\begin{array}{c}\text { Відповідальні } \\
\text { особи } \\
\end{array}$ & $\begin{array}{c}\text { Термін } \\
\text { виконання }\end{array}$ \\
\hline Етап 1 & & & & \\
\hline
\end{tabular}

Екологічна політика: Підприємство зобов'язується знизити ризикові аспекти підприємства, дотримуватись природоохоронних законодавчих вимог.

Екологічні цілі: зменшення викидів в атмосферне повітря від котельні, холодного та гарячого цехів, автотранспорту; зменшення викидів на $3 \%$.

Холодний та гарячий цехи Пара

Акролеїн
Встановлення обладнання зі збирання та Директор, конденсування пари шеф-кухар Встановлення обладнення для збирання та Директор, рециклінгу пари шеф-кухар Встановлення обладнення для вловлювання Директор, акролеїну, накопичення його в ємності та шеф-кухар знезараження.

\section{3 місяці}

3 місяці 


\begin{tabular}{|c|c|c|c|c|}
\hline & Ризик вибуху & Оновлення обладнення & $\begin{array}{l}\text { Директор, } \\
\text { шеф-кухар }\end{array}$ & 3 місяці \\
\hline & $\begin{array}{ll}\text { Посудин } & \text { П1д } \\
\text { тиском та } & \text { по- } \\
\text { жеж } & \end{array}$ & $\begin{array}{l}\text { Ремонт обладнення } \\
\text { Інструктаж працівників }\end{array}$ & $\begin{array}{l}\text { Директор, } \\
\text { шеф-кухар } \\
\text { Шеф-кухар }\end{array}$ & $\begin{array}{l}\text { Протягом тижня } \\
\text { після виявлення } \\
1 \text { раз на місяць }\end{array}$ \\
\hline Котельня & $\mathrm{CO}_{2}$ & $\begin{array}{l}\text { Встановлення обладнення вловлювання СО2 } \\
\text { Удосконалення технологічного процесу }\end{array}$ & $\begin{array}{l}\text { Директор } \\
\text { Інженер } \\
\text { котельні }\end{array}$ & 3 місяці \\
\hline Автотранспорт & $\begin{array}{l}\mathrm{CO}_{2}, \quad \mathrm{~N}_{\mathrm{x}} \mathrm{O}_{\mathrm{y}}, \\
\text { пари бензину }\end{array}$ & $\begin{array}{l}\text { Використання електротранспорту } \\
\text { Ремонт несправних автомобілей }\end{array}$ & $\begin{array}{l}\text { Директор } \\
\text { Механік }\end{array}$ & $\begin{array}{l}6 \text { місяців } \\
\text { За вимогою }\end{array}$ \\
\hline
\end{tabular}

Екологічна політика: підприємство зобов'язується зменшити скиди стічних вод

Екологічні цілі - забезпечити постійне зниження рівня забруднюючих речовин у стічних водах ресторанного закладу; знизити ГДК за вмістом завислих речовин у стічних водах на $10 \%$; зменшити викиди в стічні води синтетичних миючих засобів від хімчистки, пральні, холодного та гарячих цехів на $5 \%$; зменшити скиди в стічні води від миття сировини в овочевому та м'ясо-рибному цеху на $3 \%$.

\begin{tabular}{|c|c|c|c|c|}
\hline Пральня & $\begin{array}{l}\text { Синтетичні } \\
\text { миючі засоби }\end{array}$ & $\begin{array}{l}\text { Удосконалення технології } \\
\text { Застосування безпечних миючих засобів }\end{array}$ & Адміністратор & 1 місяць \\
\hline \multirow{3}{*}{$\begin{array}{l}\text { М'ясний, } \\
\text { холодний та } \\
\text { гарячий цехи }\end{array}$} & Жир & $\begin{array}{l}\text { Застосування жировловлювачів } \\
\text { Використання засобів для розчеплення жирів }\end{array}$ & Шеф-кухар & 3 місяці \\
\hline & $\begin{array}{l}\text { Синтетичні } \\
\text { миючі засоби }\end{array}$ & $\begin{array}{l}\text { Удосконалення технології } \\
\text { Застосування безпечних миючих засобів } \\
\text { Застосування подрібнювачів }\end{array}$ & Шеф-кухар & 1 місяць \\
\hline & $\begin{array}{l}\text { Відходи сиро- } \\
\text { вини }\end{array}$ & $\begin{array}{l}\text { Встановлення накопичувального бункеру } \\
\text { Заміна діючої технології та апаратного вико- } \\
\text { ристання і перероблення відходів }\end{array}$ & Шеф-кухар & 3 місяці \\
\hline $\begin{array}{l}\text { Душова } \\
\text { кімната }\end{array}$ & $\begin{array}{l}\text { Синтетичні } \\
\text { мийні засоби }\end{array}$ & Застосування безпечних миючих засобів & Адміністратор & 1 місяць \\
\hline \multirow{4}{*}{ Овочевий цех } & \multirow{3}{*}{$\begin{array}{l}\text { Відходи сиро- } \\
\text { вини }\end{array}$} & $\begin{array}{l}\text { Застосування подрібнювачів } \\
\text { Встановлювання накопичувального бункеру }\end{array}$ & & \multirow{3}{*}{3 місяці } \\
\hline & & Встановлення решіток & Шеф-кухар & \\
\hline & & Компостування відходів & Адміністратор & \\
\hline & Бруд & $\begin{array}{l}\text { Встановлення пісколовів } \\
\text { Попереднє очищення сировини від бруду }\end{array}$ & Шеф-кухар & 3 місяці \\
\hline \multirow{5}{*}{$\begin{array}{l}\text { Гараж, } \\
\text { автомобільна } \\
\text { стоянка }\end{array}$} & \multirow{2}{*}{$\begin{array}{l}\text { Паливно- } \\
\text { мастильні } \\
\text { матеріали }\end{array}$} & Герметизація вузлів та агрегатів автомобіля & Механік & 3 місяці \\
\hline & & Захист грунту від проливів & Директор & 3 місяці \\
\hline & $\begin{array}{l}\text { Бруд, залишки } \\
\text { грунту }\end{array}$ & Очищення автомобілів від грунту та бруду & Водій & Перед миттям \\
\hline & $\begin{array}{rr}\text { Ризик } & \text { виник- } \\
\text { нення } & \text { течі }\end{array}$ & & & \\
\hline & $\begin{array}{l}\text { паливно- } \\
\text { мастильних } \\
\text { матеріалів }\end{array}$ & Діагностика та ремонт автомобілів & Механік & Завимогою \\
\hline
\end{tabular}

Етап 3.

Екологічна політика: зменшення об’єму утворення відходів.

Екологічні цілі: Зменшення утворення харчових відходів з овочевого та м'ясо-рибного цехів; зменшення утворення побутових відходів із усіх підрозділів підприємства; утилізація та рециклінг відходів; зменшення сировинних відходів на $10 \%$; зменшення кількості побутових відходів на $15 \%$.

Удосконалення технології підготовки сиро-

2 місяці

Сировинні

відходи

Овочевий,

м'ясний, холо-

дний та гаря-

чий цехи

Ризик псування Обслуговування холодильного обладнення сировини

Удосконалення технології утилізації відходів

Шеф-кухар

ресторанного господарства

$\begin{array}{lll} & \text { сировини } & \\ & & \text { Оновлення обладнення } \\ \text { Овочевий, пакува- } & \text { Повторне використання } \\ \text { м'ясний цехи } & \begin{array}{l}\text { Пьні матеріали } \\ \text { макеральні }\end{array} & \text { Вбір макулатури } \\ & & \text { матористання багаторазових пакувальних } \\ & & \text { Сортування використаних пакувальних мате- } \\ & \text { ріалів }\end{array}$

\section{Шеф-кухар За вимогою}

2 місяці

Адміністратор За вимогою

Прибиральниця Щоденно

Шеф-кухар Щоденно

Прибиральниця Щоденно 


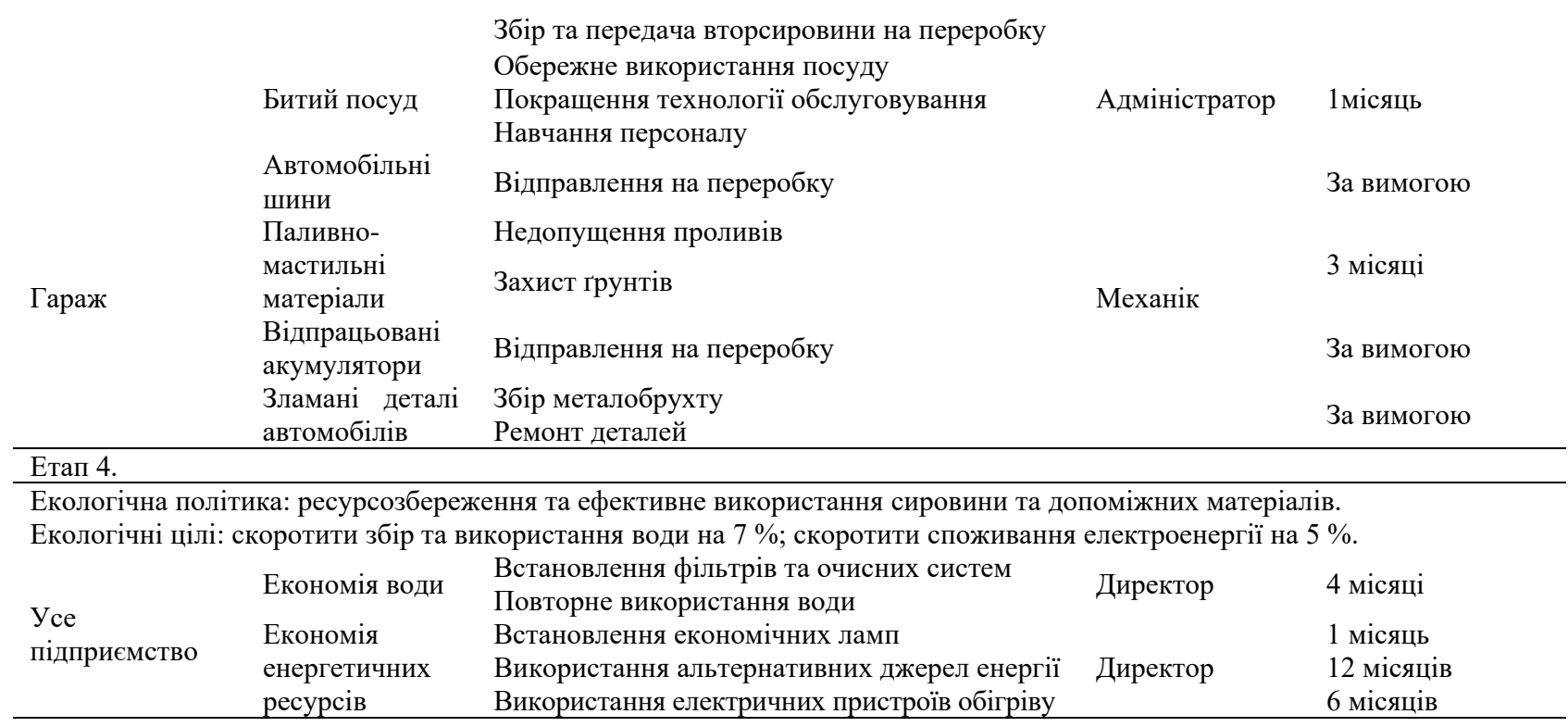

Аналіз розробленої програми природоохоронних заходів свідчить про те, що розробка та удосконалення технології компостування харчових відходів ресторанного господарства сприятиме зниженню негативного впливу на компоненти довкілля.

\section{Обговорення}

При функціонуванні ресторану існує ймовірність виникнення ризикових аспектів, пов'язаних з розливами паливно-мастильних речовин, вибухами, пожежами та ризиком санітарно-епідеміологічної небезпеки.

Ідентифікація екологічних аспектів ресторанного господарства свідчить про те, що значного впливу навколишньому природному середовищу завдають стічні води, витрати паливно-енергетичних ресурсів та відходи виробництва, зокрема харчові відходи (Zigun, 2011; Petpuk et al., 2011; Krusir \& Sokolova, 2019).

Оцінивши екологічні аспекти ресторанного комплексу за бальною шкалою визначили, що сировинні відходи справляють найбільш негативний вплив. Також використання пакувальних матеріалів, синтетичних миючих засобів, вуглеводні та викиди $\mathrm{CO}_{2}$ чинять істотний вплив на компоненти довкілля.

\section{Висновки}

Розроблена програма природоохоронних заходів системи екологічного менеджменту підприємства ресторанного господарства дасть змогу знизити негативний вплив підрозділів виробництва на довкілля за рахунок досягнення поставлених екологічних цілей та використовуючи дієві природоохоронні заходи.

\section{References}

Boiko, T., Bendiuh, V., \& Komarysta, B. (2012). Otsinka ryzyku promyslovoho pidpryiemstva na stadii proektuvannia $\mathrm{v}$ ramkakh stratehii staloho rozvytku.
Skhidno-Evropeiskyi zhurnal peredovykh tekhnolohii, 2 (14 (56)), 13-17. URL: https://cyberleninka.ru/article/ n/otsinka-riziku-promislovogo-pidpriemstva-na-stadiyiproektuvannya-v-ramkah-strategiyi-stalogo-rozvitku (in Ukrainian).

De Menna, F., Dietershagen, J., Loubiere, M. \& Vittuary, M. (2018). Life cycle costing of food waste: A review of methodological approaches. Waste Management, 73, 1-13. doi: 10.1016/j.wasman.2017.12.032.

Gworek, B., Dmuchowski, W., Koda, E., Marecka, M., Baczewska, A., Brągoszewska, P., Sieczka, A., \& Osiński, P. (2016). Impact of the Municipal Solid Waste Łubna Landfill on Environmental Pollution by Heavy Metals. Water, 8 (10), 470. doi: 10.3390/w8100470.

Hassen, A., Belguith, K., Jedidi, N., Cherif, A., Cherif, M., \& Boudabous, A. (2001). Microbial characterization during composting of municipal solid waste. Bioresource technology, 80(3), 217-225. doi: 10.1016/S09608524(01)00065-7.

Jouraiphy, A. (2005). Chemical and spectroscopic analysis of organic matter transformation composting of sewage sludge and green plant waste. International biodeterioration and biodegradation, 56, 101-108. doi: 10.1016/j.ibiod.2005.06.002.

Krusir, H. V., \& Sokolova, V. I. (2019). Doslidzhennia kompostuvannia kharchovoi skladovoi tverdykh pobutovykh vidkhodiv zakladiv hromadskoho kharchuvannia. Zb. tez dop. 79-yi nauk. konf. vykl. akad., Odesa, 16-19 kvit. 2019 r. Odes. nats. akad. kharch. tekhnolohii ; pid zah. red. B. V. Yehorova. Odesa, 312-313. URL: https://cardfile.onaft.edu.ua/jspui/handle/123456789/10327 (in Ukrainian).

Petruk, V. H., Klymenko, M. O., \& Mudrak, O. V. (2011). Vstup do fakhu. Pidruchnyk dlia studentiv napriamu pidhotovky 6.040106 "Ekolohiia, okhorona navkolyshnoho seredovyshcha ta zbalansovane pryrodoko-rystuvannia". Vinnytsia: UNIVERSUMVinnytsia. URL: http://eco.com.ua/content/vstup-dofahu-rozdil-1 (in Ukrainian). 
Sagdeeva, O., Krusir, G., \& Tsykalo, A. (2018). Investigation of the temperature regime impact on the course of composting processes of the solid municipal waste's organic component. Scientific Messenger of LNU of Veterinary Medicine and Biotechnologies. Series: Food Technologies, 20(85), 155-161. doi: 10.15421/nvlvet8528.

Shmandij, V. M., Klimenko, M. O., Golik, Ju. C., Ppishhepa, A. M., Bahapev, V. C., Haplamova, O. V. (2013). Ekologichna bezpeka. Pidpuchnyk. Hepcon: Oldi- pljuc (in Ukrainian).
Zihun, A. Y. (2011). Vykorystannia svitovoho dosvidu systemy upravlinnia vidkhodamy. Visnyk Nats. un-tu "Lviv. Politekhnika", 697, 122-126. URL: http:/ena.lp.edu.ua:8080/bitstream/ntb/10368/1/24.pdf (in Ukrainian). 